\title{
PERBANKAN SYARIAH DAN PERTUMBUHAN EKONOMI INDONESIA
}

\author{
Ali Rama \\ UIN Syarif Hidayatullah Jakarta \\ rama@uinjkt.ac.id
}

\begin{abstract}
.
The paper empirically examines the dynamic interaction between Islamic banking development, capital market, trade activities, inflation and economic growth in Indonesia using battery of time series techniques. The study documents a long-run equilibrium between Islamic banking, capital market, trade activities, inflation and economic growth. Granger causality test reveals that there is a bidirectional causality between Islamic banking-growth in Indonesia, the finding accords with "the feedback hypothesis" or bidirectional causality view". Based on the VDCs, the study discovers that the variations in the economic growth rely very much on its own innovation. The finding also shows that Islamic banking financing innovation significantly explains the variation in economic growth. To further promote contributions of Islamic banking to economic growth, the authority should provide friendly policies to accelerate its development in the country.
\end{abstract}

Keywords: Islamic Banking; Economic Growth; Inflation; Capital Market

\begin{abstract}
Abstrak.
Penelitian ini menguji secara empiris hubungan dinamis antara perkembangan perbankan syariah, pasar modal, perdagangan, inflasi dan pertumbuhan ekonomi di Indonesia dengan menggunakan data time series. Penelitian menemukan terdapat hubungan keseimbangan jangka panjang antara bank syariah, pasar modal, perdagangan, inflasi dan pertumbuhan ekonomi. Uji kausalitas Granger menunjukkan bahwa terdapat hubungan dua arah antara pertumbuhan ekonomi dengan bank syariah di Indonesia. Temuan ini sesuai dengan hipotesis dua arah. Hasil VDCs menunjukkan bahwa variasi pertumbuhan ekonomi sangat tergantung pada variasinya sendiri. Penelitian juga menemukan bahwa variasi pembiayaan bank syariah dapat menjelaskan secara signifikan variasi pertumbuhan ekonomi. Dalam rangka meningkatkan kontribusi perbankan syariah terhadap pertumbuhan ekonomi, pihak terkait harus menyediakan kebijakan yang tepat untuk mempercepat pertumbuhan perbankan syariah di Indonesia.
\end{abstract}

Kata Kunci: Bank Syariah; Pertumbuhan Ekonomi; Inflasi; Pasar Modal

Diterima: 2 Desember 2012; Direvisi: 10 Februari 2013; Disetujui: 5 Maret 2013 


\section{PENDAHULUAN}

Hubungan antara sektor keuangan - diartikan sebagai peningkatan volume produk dan jasa perbankan dan lembaga-lembaga intermidiasi lainnya serta transaksi keuangan di pasar modal - dan pertumbuhan ekonomi telah lama menjadi objek penelitian dalam bidang ilmu ekonomi pembangunan. Perkembangan sektor keuangan berpengaruh terhadap pertumbuhan ekonomi, begitupula sebaliknya. Jika sektor keuangan mengalami pertumbuhan yang baik maka akan semakin banya sumber pembiayaan yang dapat dialokasi ke sektor-sektor ekonomi produktif dan pada akhirnya akan menambah pembangunan modal sektor ekonomi untuk meningkatkan produktivitasnya dalam menunjang pertumbuhan ekonomi.

Kinerja positif sektor keuangan akan berkorelasi positif terhadap kinerja ekonomi suatu negara. Sektor keuangan bisa menjadi sumber utama pertumbuhan sektor riil ekonomi. Semakin banyak alokasi dana pihak ketiga perbankan yang dialokasikan pada sektorsektor riil maka akan semakin berkurang tingkat pengangguran dan kemiskinan dalam sebuah perekonomian. Sejumlah penelitian telah menunjukkan bahwa sektor perbankan berperan penting dalam menunjang pertumbuhan ekonomi dan kesejahteraan suatu negara. Saat ini, hampir semua sektor bisnis khususnya di negara-negara berkembang sangat tergantung terhadap pembiayaan perbankan sebagai sumber modal pembiayaan.

Pihak yang memiliki kelebihan dana (modal) akan menginvestasikan dananya ke lembaga keuangan (sebagai lembaga intermediasi) yang selanjutnya akan disalurkan ke sektor bisnis yang membutuhkan pembiayaan. Kemampuan bank dalam memperluas pembiayaan sangat tergantung pada kemampuannya untuk memobilisasi dana pihak ketiga dari masyarakat. Kondisi ini, mendorong munculnya tingkat persaingan di kalangan institusi perbankan (baik perbankan syariah maupun konvensional) dalam mengumpulkan dana pihak ketiga (tabungan) begitupula dalam menyalurkan pembiayaan ke sektor bisnis yang menguntungkan.

Industri keuangan dan perbankan syariah saat ini mengalami peningkatan peminat khususnya setelah terjadinya krisis keuangan global 2007/2008. Hasilnya, industri keuangan syariah tidak lagi hanya menjadi sekedar "peripheral" atas sistem konvensional, akan tetapi sudah berperan menjadi pelengkap yang memiliki potensi untuk dikembangkan di masa yang akan datang sebagai alternatif terhadap sistem konvensional yang sudah lama beroperasi. 
Implementasi strategi pengembangan perbankan syariah di beberapa negara ada yang menggunakan pendekatan sistem perbankan syariah secara penuh (full-fledged Islamic banking system) seperti Pakistan, Iran dan Sudan. Adapun negara seperti Indonesia, Malaysia, Bahrain, Kuwait dan negara lainnya menganut sistem dual banking, dimana sistem perbankan syariah beroperasi berdampingan dengan sistem konvensional dalam sebuah negara.

Perbankan syariah sebagai bagian dari sistem perbankan nasional mempunyai peranan penting dalam perekonomian. Peranan perbankan syariah dalam aktivitas ekonomi tidak jauh berbeda dengan perbankan konvensional. Keberadaan perbankan syariah dalam sistem perbankan nasional di Indonesia diharapkan dapat mendorong perkembangan perekonomian nasional. Perbedaan mendasar antara perbankan syariah dan konvensional terletak pada prinsip-prinsip dalam transaksi keuangan dan operasional.

Secara teoritis, perbankan syariah berbeda dengan perbankan konvensional. Bank syariah terikat dengan ketentuan-ketentuan yang ada dalam al-Qur'an dan al-Hadist. Transaksi-transaksi pada perbankan syariah harus terhindar dari interest (riba) dan kontrak-kontrak yang mengandung ketidakpastian (gharar dan maysir), menekankan pada prinsip bagi hasil dan risiko, mengutamakan investasi pada sektor ekonomi halal dan harus didasari pada transaksi riil (asset-based) (Rama, 2011).

Bank syariah sebagai lembaga intermediasi diartikan sebagai bank yang mengumpulkan dana dari masyarakat dalam bentuk tabungan dan deposito kemudian dana yang terkumpul tersebut diinvestasikan pada sektor ekonomi yang dibolehkan secara syariah. Bank syariah dan konvensional secara fungsi memiliki beberapa kesamaan khususnya pada pengumpulan dana pihak ketiga melalui tabungan dan investasi. Namun kedua sistem itu sangat berbeda pada instrumen pembiayaannya. Bank syariah mengembangkan instrumen pembiayaan non bunga (interest-free financing instruments) yang berdasarkan pada dua prinsip, yaitu bagi hasil dan risiko (profit- and loss-sharing) dan tambahan margin (mark-up margin). Sedangkan bank konvensional menganut pinjaman (loan) berdasarkan interest (riba) ( Rama, 2011).

Salah satu ciri utama perbankan syariah yang berdampak positif terhadap pertumbuhan sektor riil dan ekonomi yaitu bahwa lembaga keuangan syariah lebih menekankan pada peningkatan produktivitas. Lembaga keuangan syariah adalah lembaga keuangan yang menekankan konsep asset \& production based system 
(sistem berbasis aset dan produksi) sebagai ide utamanya. Mudharabah dan musharakah adalah cerminan utama dari ide tersebut. Melalui pola pembiayaan seperti itu maka sektor riil dan sektor keuangan akan bergerak secara seimbang. Akibatnya semakin tumbuh perbankan syariah maka akan semakin besar kontribusinya terhadap kinerja dan pertumbuhan ekonomi. Jumlah kemiskinan dan pengangguran secara langsung akan teratasi melalui kinerja ekonomi yang baik.

Paradigma dalam konsep keuangan dan perbankan syariah adalah risk sharing yaitu mendorong para deposan dan pihak bank untuk sama-sama berbagi risiko bisnis. Konsep ini akan membuat para deposan untuk berhati-hati dalam memilih bank, dan sekaligus memotivasi manajemen bank untuk berhati-hati dalam menyalurkan pembiayaan atau dalam melakukan investasi (Chapra, 2008). Oleh karenanya, keuangan syariah lebih menekankan pada jenis pembiayaan ekuitas (equity financing). Jenis pembiayaan ini lebih diprioritaskan. Hal ini dikarenakan melalui pola ini pemilik dana akan ikut berpartisipasi dalam risiko sehingga mereka akan berhati-hati dalam mengelola risiko dan tetap melakukan pengawasan terhadap aktivitas pihak peminjam. Model pembiayaan lainnya adalah pembiayaan berbasis jual beli (sale-based modes of financing). Model pembiayaan perbankan syariah ini akan sangat mendukung peningkatan produksi barang dan jasa secara riil. Akhirnya, konsep bagi hasil (musyarakah dan mudharabah) dan jual beli serta sewa akan berdampak terhadap pertumbuhan sektor ekonomi riil dan pada akhirnya mendorong terjadinya pertumbuhan ekonomi secara nasional.

Indonesia adalah negara berpenduduk Muslim terbesar di dunia dan memiliki perekonomian terbesar di Asia Tenggara, tetapi jika dilihat dari segi pangsa pasar industri keuangan syariah nasional (pangsa pasar hanya sekitar 4 persen per Juli 2012) masih jauh tertinggal dengan negara-negara lain, seperti Malaysia yang pangsa pasar industri keuangannya telah mencapai 20 persen dari total aset perbankan nasionalnya. Akan tetapi, dengan kinerja ekonomi nasional yang semakin membaik, pertumbuhan ekonomi 2011 sebesar 6.5 persen, Produk Domestik Bruto (PDB) yang mencapai Rp7.000 trilliun, potensi pertumbuhan pangsa pasar keuangan syariah masih terbuka lebar, akan membangun optimisme masa depan industri keuangan syariah di Indonesia.

Badan Pusat Statistik mempublikasikan hasil kinerja perekonomian Indonesia kuartal II/2012 yang menunjukkan bahwa pertumbuhan ekonomi Indonesia tahun ini mencapai 
6,4 persen dibandingkan dengan periode tahun sebelumnya. Secara kumulatif, pertumbuhan ekonomi Indonesia semester II/2012 dibandingkan dengan semester I/2011 tumbuh sebesar 6,3 persen. Tentunya angka pertumbuhan ini membuat pemerintah optimis untuk mencapai target pertumbuhan ekonomi 2012 sebesar 6,5 persen.

Setelah dilanda krisis keuangan 1997, pertumbuhan ekonomi nasional mulai membaik pada tahun 2002 dengan tingkat pertumbuhan $4,3 \%$ dan terus meningkat jadi $6,2 \%$ tahun 2007. Namun sempat menurun menjadi 4,5\% tahun 2009 akibat krisis keuangan yang melanda ekonomi AS dan kembali naik pada tahun 2010 menjadi 6,1\% dan terus meningkat menjadi 6,5 persen pada tahun 2011. Angka ini telah mengantarkan Indonesia di urutan ke 3 di Asia dan tertinggi kedua di G-20 setelah China. Berdasarkan prediksi pemerintah, jika tidak ada guncangan ekonomi yang berarti maka pertumbuhan ini akan terus menanjak mencapai lebih dari 7\% pada akhir tahun 2014.

Pertumbuhan lembaga-lembaga keuangan syariah yang cukup signifikan dan pertumbuhan ekonomi yang tinggi di waktu yang bersamaan menarik minat untuk dilakukan kajian apakah sektor perbankan syariah yang saat ini mengalami peningkatan minat dan pertumbuhan secara fantastik dan konsisten (tumbuh rata-rata $40 \%$ per tahun) benar-benar berkontribusi secara empiris dalam pertumbuhan ekonomi Indonesia dalam jangka panjang. Untuk melakukan hal ini, kami akan menganalisis hubungan dinamis (dynamic interactions) antara sektor perbankan dan pertumbuhan ekonomi. Apakah perbankan syariah berpengaruh terhadap pertumbuhan ekonomi atau pertumbuhan ekonomi yang mempengaruhi perbankan syariah. Untuk lebih fokus dalam penelitian ini, maka permasalahan yang akan diteliti dibatasi pada identifikasi hubungan dinamis dan hubungan sebab akibat (causal relationship) antara sektor perbankan syariah dan variabel kontrol lainnya terhadap pertumbuhan ekonomi dalam konteks perekonomian Indonesia. Pengaruh perkembangan perbankan syariah terhadap pertumbuhan ekonomi dan sebaliknya.

Hubungan antara perkembangan sektor keuangan dan pertumbuhan ekonomi telah menjadi objek penelitian dalam berbagai literatur ekonomi pembangaunan dan keuangan. Isu tentang keuangan dan pertumbuhan setidaknya telah dikemukakan sejak abad ke 19 oleh Joseph A. Schumpeter yang mengemukakan tentang urgensi sistem perbankan dan pertumbuhan tingkat pendapatan nasional dalam 
pembangunan ekonomi melalui identifikasi dan pembiayaan pada sektor investasi yang produktif (Schumpeter, 1912).

Pengembangan teori pertumbuhan ekonomi telah secara luas digunakan sebagai literatur dalam studi bidang pembangunan ekonomi, makroekonomi dan bidang studi lain yang berhubungan dengannya. Beberapa dari teori tersebut diperkenalkan oleh Rostow, Harrod, Domar, Lewis, dan Solow. Namun hanya beberapa dari teori tersebut yang fokus terhadap peranan sektor keuangan dalam mendorong pertumbuhan ekonomi. Di sisi yang lain, Harrod (1939) dan Domar (1946) berpendapat bahwa untuk meningkatkan tingkat pertumbuhan maka diperlukan peningkatan investasi baru, sehingga rasio tabungan nasional dan pendapatan nasional menentukan tingkat pertumbuhan ekonomi. Sedangkan Solow (1956) dalam pemikiran neoklasik teori pertumbuhannya adalah hasil pengembangan dari teori pertumbuhan Harrord-Domar dengan hanya menambahahkan faktor lain, tenaga kerja (labour) dan memperkenalkan variabel independen ketiga berupa teknologi dalam persamaan teori pertumbuhan.

Saat ini telah banyak hasil penelitian yang berusaha mengkaji secara empiris dengan cara mengeksplorasi indikator-indikator yang lebih spesifik untuk menjelaskan hubungan sebab akibat antara sektor keuangan dan pertumbuhan ekonomi. Setidaknya ada empat kemungkinan pendekatan yang bisa menjelaskan hubungan sebab akibat antara keuangan dan pertumbuhan, yaitu: 1) Keuangan adalah faktor penentu pertumbuhan ekonomi (finance-led growth hypothesis) atau biasa disebut "supply-leading view", 2) Keuangan mengikuti pertumbuhan ekonomi (growth-led finance hypothesis) atau biasa disebut "demand-following view", 3) Hubungan saling mempengaruhi antara keuangan dan pertumbuhan atau biasa disebut "the bidirectional causality view", dan 4) Keuangan dan pertumbuhan tidak saling berhubungan atau biasa disebut "the independent hypothesis".

Pertama adalah "the finance-led growth hypothesis" atau "supply-leading view". Teori ini secara umum menganggap bahwa sektor keuanganlah yang mendorong pertumbuhan ekonomi. Teori ini pada dasarnya mencari hubungan antara keuangan dan pembangunan ekonomi. Para penganut teori ini meyakini bahwa keberadaan sektor keuangan yang berperan sebagai lembaga intermediasi antara pihak yang kelebihan modal (surplus unit) dengan pihak yang kekurangan modal (deficit unit) akan menyediakan alokasi sumber-sumber pendanaan yang efisien 
yang nantinya akan menggerakkan sektor-sektor ekonomi dalam proses pertumbuhannya. Hasil penelitian empiris yang dilakukan oleh Xu (2000), Arestis et al. (1996), dan Fase dan Abma (2003) menunjukkan bahwa ekspansi sektor keuangan berpengaruh secara positif terhadap pertumbuhan ekonomi. Horrison et al. (1999) dan Blackburn dan Hung (1998) mengemukakan bahwa fungsi intermediasi lembaga sektor keuangan akan mendorong pertumbuhan ekonomi, ini dikarenakan akan mengurangi biaya dalam penilaian proyek. Jika jumlah proyek meningkat dalam perekonomian yang bertumbuh maka bank akan masuk ke dalam pasar sebagai bentuk aktivitas bank dan keuntungan akan bertambah. Pertambahan jumlah bank akan mengurangi rata-rata jarak antara bank dan debitor, mendorong spesialisasi dan mengurangi biaya intermiediasi. King dan Levini (1993) adalah salah satu yang telah membuktikan bahwa pertumbuhan sektor keuangan adalah sebagai syarat untuk mencapai pertumbuhan ekonomi.

Akan tetapi banyak peneliti yang meragukan tentang hipotesis ini (financial-led growth). Demetriades dan Hussein (1996) dengan menggunakan data tahunan dari 1965 sampai 1992 menemukan diantara negera-negara Asia yang ditelitinya, hanya Sri Lanka yang membuktikan hipotesis financial-led growth. Studi di Turki dalam periode 1986.Q1 sampai 2006.Q4, Acaravei et al. (2007) hanya menemukan hubungan satu arah dari sektor keuangan ke pertumbuhan ekonomi, tetapi secara statistik dalam jangka panjang hubungan antara sektor keuangan dan pertumbuhan ekonomi tidak signifikan.

Kedua adalah "the growth-led finance hypothesis" atau "the demand-following view". Pemikiran ini dikembangkan oleh Robinson (1952), inti pemikirannya adalah perkembangan sektor keuangan mengikuti pertumbuhan ekonomi atau aktivitas wirausaha (enterprise) mendorong pertumbuhan sektor keuangan. Jika sektor ekonomi mengalami ekspansi maka permintaan terhadap produk dan jasa perbankan juga akan mengalami peningkatan, sehingga dengan sendirinya sektor perbankan akan juga meningkat. Penelitian empiris yang mendukung hipotesis ini telah banyak dilakukan. Diantaranya adalah Habibullah (2006) dalam penelitiannya di tujuh negara Asia menemukan Malaysia, Nyamar dan Nepal mendukung hipotesis "growth-led finance" dan hanya Filipina yang mendukung hipotesis "finance-led growth". 
Ketiga adalah "the bidirectional causality view". Aliran pemikiran ekonomi ini menggambarkan hubungan dua arah atau saling mempengaruhi antara sektor perkembangan keuangan dan pertumbuhan ekonomi. Hipotesis ini menyatakan bahwa sebuah negara yang memiliki perkembangan sektor keuangan yang baik akan mendorong tingkat ekspansi ekonomi yang tinggi melalui kemajuan teknologi dan inovasi produk dan jasa (Schumpeter, 1912).

Kondisi ini kemudian akan menciptakan tingkat permintaan yang tinggi terhadap produk dan layanan perbankan (Lihat Levine, 1997). Jika institusi perbankan merespon secara efektif terhadap permintaan tersebut, maka respon tersebut akan menstimulasi kinerja ekonomi yang lebih tinggi. Sektor keuangan dan pertumbuhan ekonomi masingmasing saling berhubungan secara positif dan hubungan ini terjadi secara dua arah (Lihat Choong dkk, 2003). Penelitian empiris yang mendukung hipotesis ini juga sudah banyak dilakukan.

Penelitian yang dilakukan oleh Odedokun (1992) dan Luintel dan Khan (1999) menemukan hubungan dua arah antara sektor keuangan dan pertumbuhan ekonomi. Sektor keuangan dan perkembangan ekonomi saling mempengaruhi, pertumbuhan sektor keuangan menyebabkan ekonomi bertumbuh dan pertumbuhan ekonomi mendorong sektor keuangan untuk berkembang secara maju. Demetriades dan Husaen (1996) dalam penelitiannya terhadap negara-negara Asia tidak hanya membuktikan hipotesis "the finance-lead growth" dan hipotesis "the growth-led finance" di antara negara-negara Asia, tapi juga menemukan hubungan saling mempengaruhi, hubungan dua arah antara sektor keuangan dan pertumbuhan ekonomi yang terjadi di India, Korea Selatan dan Thailand. Hubungan dua arah ini juga terjadi di Indonesia pada penelitian yang dilakukan oleh Habibullah (1999). Dengan menggunakan data tahunan dari 1970 sampai 2001. Sementara di Turki, Unalmis (2002) menemukan bahwa dalam jangka panjang dengan menggunakan pendekatan VECM atas nilai koefisiensi yang terintegrasi menunjukkan bahwa ada hubungan saling mempengaruhi antara keuangan dan pertumbuhan ekonomi.

Keempat adalah "the independent hypothesis" atau tidak ada hubungan saling mempengaruhi antara keuangan dan pertumbuhan ekonomi. Hipotesis ini diperkenalkan oleh Lucas (1988) yang berpendapat bahwa sektor keuangan dan pertumbuhan ekonomi tidak memiliki hubungan saling mempengaruhi. Guryay dkk (2007) menguji hubungan antara sektor keuangan dan pertumbuhan ekonomi untuk 
negara Cyprus dari periode 1986 sampai 2004. Hasilnya menunjukkan bahwa sektor ekonomi tidak memiliki pengaruh terhadap pertumbuhan ekonomi di Cyprus. Selanjutnya, Al-Zubi dkk (2006) menggunakan model yang dikembangkan oleh Levine pada tahun 1997 yang menggunakan panel data terhadap 11 negara Arab dari periode 1980 sampai 2001.

Hasilnya menunjukkan bahwa semua indikator keuangan tidak signifikan dan tidak berpengaruh terhadap pertumbuhan ekonomi. Model yang telah dikembangkan menunjukkan hanya indikator kredit dalam negeri saja yang signifikan dan memiliki efek positif tehadap pertumbuhan ekonomi. Hal ini membuktikan bahwa dominasi sektor publik dalam aktivitas ekonomi dan sektor keuangan masih belum berkembang dan butuh usaha-usaha agar dapat mengembangkan fungsinya secara efektif di negara-negara Arab. Sementara itu penelitian yang dilakukan oleh Galindo dan Micco (2004) yang menggunakan data cross section negara menunjukkan bahwa bank-bank milik negara tidak mendorong pertumbuhan industri-industri manufaktur yang hanya mengandalkan sumber pembiayaan eksternal untuk operasionalnya.

Sementara itu dalam sistem keuangan Islam, penelitian empiris sejauh ini yang telah dilakukan untuk menganalisis tingkat efisiensi, superioritas dan stabilitas bank-bank Islam dibandingkan bank-bank konvensional untuk mencapai target fungsi intermediasi moneter yang difokuskan pada pencapaian kesinambungan pertumbuhan riil ekonomi, penurunan inflasi dan pengangguran. Hasinya menunjukkan bahwa sistem keuangan yang tidak menggunakan bunga (interest-free banking system) adalah lebih unggul dalam mencapai target moneter (lihat Darrat, 1988). Sementara itu Yousefi dkk (1997) dan Yusuf dan Wilson (2005) menemukan bahwa tidak ada bukti secara empiris yang menunjukkan keunggulan dan stabilitias sistem bank non-riba dibandingkan dengan bank yang menggunakan riba (interest based banking system).

Selanjutnya, Hafas dan Mulyani (2009) dalam penelitiannya tentang kontribusi perbankan Islam terhadap perekonomian Malaysia menemukan adanya hubungan yang signifikan antara pertumbuhan ekonomi dan dana pihak ketiga yang dikumpulkan oleh bank-bank Islam. Penelitian secara empiris yang membahas secara spesifik hubungan sektor keuangan Islam terhadap pertumbuhan ekonomi masih sangat terbatas sekali.

Sementara itu dalam konteks Indonesia, penelitian empiris tentang hubungan sektor keuangan dan pertumbuhan ekonomi Indonesia telah banyak dilakukan. Hidayati 
(2009) yang menginvestigasi hubungan kausalitas antara sektor keuangan dengan pertumbuhan ekonomi Indonesia. Dengan menggunakan sektor perbankan dan pasar modal sebagai representasi sektor keuangan, Hidayati menggunakan impulse respon function dan variance decomposition dan menemukan bahwa perubahan pada sektor perbankan lebih berperan dalam menjelaskan adanya perubahan pada pertumbuhan ekonomi dibandingkan dengan perubahan pada pasar modal.

Sedangkan hasil kausalitas Granger menunjukkan adanya bi-directional causality antara pertumbuhan ekonomi dan perkembangan volume kredit perbankan, serta kausalitas satu arah antara perkembangan kapitalisasi pasar saham dan pertumbuhan ekonmi. Sementara, Inggrid (2008) dalam penelitiannya yang menggunakan Vector Error Correction Model (VECM) cenderung mendukung hipotesis bahwa sistem keuangan dapat menjadi mesin pertumbuhan di Indonesia (the finance-led growth). Berdasarkan uji kausalitas Granger menunjukkan adanya bidirectional causality antara output riil dan volume kredit serta one-way causality yang berasal dari spread menuju output riil. Namun dalam konteks analisis kontribusi perbankan syariah terhadap pertumbuhan ekonomi Indonesia masih sangat minim sekali bahkan mungkin belum ada, mungkin disebabkan adanya keterbatasan data.

\section{METODE}

\section{Sumber Data dan Variabel Penelitian}

Penelitian ini menggunakan data time series selama kurun waktu 2002-2012 dimana data bulanan sebagai basis datanya. Data time series tersebut didapatkan melalui laman laporan bulanan Bank Indonesia dan International Financial Statistics (IFS). Adapun variabel yang digunakan adalah total pembiayan (Total Financing) dan total dana pihak ketiga (Total Deposit) perbankan syariah sebagai representasi sektor keuangan perbankan syariah. Industrial Production Index (IPI) sebagai pengganti GDP (Gross Domestic Product) sebagai representasi pertumbuhan ekonomi. Variabel tambahan lainnya adalah aktivitas perdagangan (Trade) yang merupakan penjumlahan volume ekspor dan impor, Cunsumer Price Index (CPI) atau Indeks Harga Konsumen sebagai represesntasi tingkat inflasi dan Jakarta Composite Index (JCI) sebagai representasi dari sektor pasar modal. Semua data time series masing-masing variabel dalam penelitian adalah dalam bentuk logaritma (log) kecuali IPI. 


\section{Model dan Metodologi Penelitian}

Variabel yang kami gunakan dalam penelitian ini adalah total Industrial Production Index (IPI), total pembiayaan (TF), total dana deposit (TD), Cunsomer Price Index (INF) dan Openess of Economy (OE). Dalam penelitian ini kami menggunakan dua model untuk menilai kontribusi sektor perbankan syariah dan variabel kontrol lainnya terhadap pertumbuhan ekonomi, yaitu:

$$
\begin{aligned}
& \mathrm{IPI}_{\mathrm{t}}=\beta_{1}+\beta_{2} \mathrm{LnTD}_{2 \mathrm{t}}+\beta_{3} \mathrm{LnTrade}_{3 \mathrm{t}}+\beta_{4} \mathrm{LnJCI}_{4 \mathrm{t}}+\beta_{4} \operatorname{Inf}_{5 \mathrm{t}}+\varepsilon_{\mathrm{t}} \ldots \ldots . .1 \\
& \mathrm{IPI}_{\mathrm{t}}=\beta_{1}+\beta_{2} \mathrm{LnTF}_{2 \mathrm{t}}+\beta_{3} \mathrm{LnTrade}_{3 \mathrm{t}}+\beta_{4} \mathrm{LnJCl}_{4 \mathrm{t}}+\beta_{4} \operatorname{Inf}_{5 \mathrm{t}}+\mu_{\mathrm{t}} \ldots \ldots . .2
\end{aligned}
$$

penelitian ini menggunakan teknik investigasi time series dengan nama model Vector Autoregression dimana termasuk di dalamnya tes kointegrasi dan analisis impulse response (IRF) serta variance decomposition. Tahapan-tahapan investigasi dengan menggunakan teknik ekonometrik time series adalah sebagai berikut: (i) tes unit root dan kointegrasi; (ii) spesifikasi dan estimasi VAR; dan (iii) analisis impulse response dan variance decomposition. Secara spesifik untuk melihat hubungan sebab akibat antara sektor perbankan dengan pertumbuhan ekonomi, penelitian ini menggunkana test Causality Granger.

\section{Uji Akar Unit (Unit Root Test)}

Estimasi model ekonometrik time series akan menghasilkan kesimpulan yang tidak berarti ketika data yang digunakan mengandung akar unit (tidak stasioner). Nonstationary seri akan menghasilkan model yang spurious regression, yaitu kondisi dimana hasil regresinya menunjukkan nilai koefisiensi deeterminasi yang tinggi, $R^{2}$ dan t statistik yang signifikan, tetapi secara teori tidak memiliki hubungan yang berarti.

Time series dikatakan stasioner jika rata-rata varians dan kovariansnya konstan sepanjang periode waktu. Untuk melihat stasionaritas variabel time series maka penelitian ini menggunakan Augmented Dickey-Fuller test (ADF test) yang diperkenalkan oleh Dickey Fuller (1979) dan Phillips-Perron test (PP test) yang diperkenalkan oleh Phillips Perron (1988). Adapun model ADF tes adalah (Gujarati, 2009):

$$
\Delta \mathrm{Y}_{\mathrm{t}}=\beta_{1}+\beta_{2} \mathrm{t}+\delta \beta_{\mathrm{t}-1}++\varepsilon_{\mathrm{t}}
$$

Adapun $\beta_{1}$ dan $\beta_{2}$ t adalah parameter, $t$ adalah waktu dan tren variabel, $\delta$ menunjukkan drift $\varepsilon_{\mathrm{t}}$ adalah murni noise error term. Jika hipotesis nol $\left(\mathrm{H}_{0}\right)$ adalah $\delta=0$ maka 
terdapat unit root, berarti data time series tidak stasioner. Sementara apabila Hipotesis alternative $<0$, berarti time series stasioner. Atau jika nilai statistik ADF secara absolut lebih besar daripada nilai kritis MacKinnon maka hipotesis $\mathrm{H}_{0}$ ditolak, artinya times series stasioner.

Time series yang tidak stasioner dapat dijadikan stasioner melalui proses diferensiasi. Diferensiasi pada derajat pertama dapat dinyatakan sebagai berikut:

$$
\Delta^{2} Y_{t}=\beta_{1}+\beta 2 \Delta Y_{t-1}+\varepsilon_{t} \ldots \ldots .4
$$

Jika data time series telah stasioner maka disebut stasioner pada derajat pertama, I (1).

Adapun PP tes berbeda dengan ADF tes. PP tes fokus pada serial korelasi dan heteroskedasticity pada error term. Model PP tes adalah:

$$
\Delta \mathrm{Z}_{\mathrm{t}}=\alpha+\theta_{\mathrm{t}}+\lambda_{\mathrm{t}-1}+\mu_{\mathrm{t}}
$$

Hipotesis nol $\left(\mathrm{H}_{0}\right)$ adalah $\lambda=0$, artinya $\mathrm{Z}$ tidak stasioner, sedangkan hipotesis alternatif $\left(\mathrm{H}_{\mathrm{a}}\right)$ adalah stasioner.

Analisis tahap pertama bertujuan untuk menguji apakah ada unit root (akar unit) pada variabel-variabel penelitian dengan menggunakan tes Augmented Dickey-Fuller (ADF) dan Phillips-Perron (PP). Jika kondisi stasionaritas data telah diketahui, maka tes selanjutnya yang akan dilakukan adalah tes kointegrasi.

\section{Uji Kointegrasi Johansen (Johansen Cointegration Test) dan VECM}

Kombinasi dari dua series yang tidak stasioner, akan bergerak ke arah yang sama menuju ekuilibrium jangka panjangnya dan diferensiasi diantara kedua time series tersebut akan konstan. Jika demikian halnya, time series tersebut dikatakan saling berkointegrasi, berarti variabel-variabel tersebut bergerak bersama dan memiliki hubungan jangka panjang.

Untuk menguji secara empiris hubungan jangka panjang antara sektor perbankan syariah dengan pertumbuhan ekonomi dan hubungan saling mempengaruhi antara keuangan Islam (perbankan syariah) dengan pertumbuhan ekonomi maka kami menggunakan uji kointegrasi Johansen. Tes kointegrasi antara perkembangan sektor keuangan dengan pertumbuhan ekonomi berdasarkan pendekatan Vector Autocorrelation Regression (VAR) Johansen. Jika vektor $\mathrm{Y}_{\mathrm{t}}$ adalah vektor variabel endogen dalam VAR dengan panjang lag $p$, maka: 


$$
Y t=\Phi_{1} Y_{t-1}+\Phi_{2} Y_{t-2}+\ldots+\Phi_{1} Y_{t-1}+\beta X t+\eta_{t}, \quad t=1, \ldots, T, \ldots \ldots .6
$$

Dimana:

$\mathrm{W}_{\mathrm{t}} \quad$ = vektor variabel endogen

$\Phi_{1} \quad=$ parameter matriks

$\beta X_{t} \quad=d$-vektor dari deterministic variabel

$\eta_{\mathrm{t}} \quad=$ vektor innovations

spesifikasi VAR ini dapat dinyatakan dalam bentuk first different sebagai Vector Error correction (VECM) sebagai berikut:

$$
\Delta Y_{t}=\Gamma_{1} \Delta Y_{t-1}+\Gamma_{2} \Delta Y_{t-2}+\ldots+\Gamma_{1-1} \Delta Y_{t-1+1}+\Pi Y_{t-1}+\beta X t+\eta_{t}, t=1, \ldots, T \ldots \ldots . .7
$$

Dimana:

$\Gamma \quad=$ adalah estimated parameters

$\Delta \quad=$ difference operator

$\Pi \quad=$ parameter matriks jangka panjang

Jika tidak terdapat hubungan kointegrasi, model unrestricted VAR dapat diaplikasikan. Tetapi bila terdapat hubungan kointegrasi antar variabel, model Vector Error Correction (VECM) yang digunakan.

Engle dan Granger (1988) mengemukakan bahwa VECM memiliki kemampuan untuk membedakan efek kausalitas antara jangka pendek dan jangka panjang. Model VECM fokus pada periilaku jangka panjang pada variabel endogenous untuk memusatkan hubungan kointegrasinya sementara itu membiarkan penyesuaian jangka pendeknya. Istilah kointegrasi merujuk pada koreksi ketika series jangka panjangnya mengoreksi deviasi pada keseimbangan jangka pajang.

Impulse Response Function dan Variance Deomposition.

Penelitian ini juga menggunakan variance decomposition (VDCs) untuk menggali lebih dalam hubungan dinamis antar variabel. VDCs memungkinkan kita untuk menguji diluar dari kausalitas sampel antar variabel di dalam sistem VAR. Metode ini mengukur persentase dari variasi variabel yang bisa dijelaskan oleh variabel yang lain. Dengan kata lain, untuk menunjukkan dampak suatu variabel terhadap variabel yang lain. Di saat yang bersamaan, VDCs menyajikan informasi bagaimana sebuah variabel merespon jika terjadi inovasi atau shock pada variabel yang lain. Akibatnya, dalam konteks penelitian ini, metode ini memungkinkan kita untuk menginvestigasi pentingnya perkembangan keuangan dalam mengukur variasi pertumbuhan ekonomi. 
Untuk menginterpretasikan implikasi ekonomi dari hasil VDCs, maka kami menggunakan prosedur pengukuran inovasi yang dikembangkan oleh Sim (1980). Prosedur ini melibatkan dekomposisi peramalan varians error tiap-tiap variabel terhadap komponen atribut ke dalam inovasinya masing-masing dan ke shock variabelvariabel yang lain di dalam sistem.

\section{HASIL DAN PEMBAHASAN}

\section{Uji Akar Unit (Unit Root Test)}

Metode VAR mengharuskan semua variabel dalam sistem untuk stasioner. Sehingga harus dilakukan uji stasionaritas terlebih dahulu pada tiap-tiap variabel. Uji akar unit dilakukan untuk menentukan stasionaritas data runtut waktu (time series). Data time series dikatan stasioner jika rata-rata, varian dan kovarian pada setiap lag adalah tetap sama pada setiap waktu. Jika data time series tidak memenuhi kriteria tersebut maka data dikatakan tidak stasioner (Widarjono, 2009). Jika data time series memiliki akar unit maka dikatakan data series tersebut bergerak secara random (random walk) dan data yang bersifat random walk dikatakan tidak stasioner.

Untuk mengetahui stasionaritas data time series digunakan uji Augmented DickeyFuller (ADF) dan Phillips-Perron (PP) terhadap semua variabel, yaitu industrial production Index (IPI), total deposito (LnTD), total financing (LnTF), aktivitas perdagangan (LnTrade), Jakarta Composite Index (LnJCl) dan tingkat inflasi (Inf). Tabel 1 menyajikan hasil uji ADF dan PP pada tingkat level dan first difference atas masing-masing variabel. Berdasarkan uji akar ADF dan PP menunjukkan bahwa beberapa variabel memiliki stasionaritas yang berbeda pada level. Variabel LnTD dan IPI stasioner pada level untuk masing-masing uji ADF dan PP, sedangkan LnTF hanya stasioner pada uji PP dan sebaliknya pada ADF. Sementara yang lainnya tidak stasioner pada level. Oleh karenanya, semua variabel pada umumnya tidak stasioner pada level. Hasil ini menujukkan bahwa variabel-variabel pada level gagal untuk menolak $\mathrm{H}_{0}$, yaitu stasioner pada level $5 \%$. Sehingga semua variabel memiliki unit root pada tingkat level. Akan tetapi, seluruh varaibel atau series stasioner setelah dideferensiasikan pada orde pertama, I(1). Artinya, semua series berintegrasi pada orde pertama. Ini mengindikasikan adanya kemungkinan hubungan jangka panjang di antara variabel dalam sistem. Jika semua series stasioner pada orde yang sama maka selanjutnya dilakukan uji kointegrasi untuk melihat hubungan jangka panjang antar variabel. 
Tabel 1. Hasil Uji Akar Unit

\begin{tabular}{lccccc}
\hline \multirow{2}{*}{ Variabels } & \multicolumn{2}{c}{ Level } & & \multicolumn{2}{c}{ Fist Difference } \\
\cline { 2 - 3 } \cline { 5 - 6 } & ADF & PP & & ADF & PP \\
\hline LnTD & $-3.100934^{* *}$ & $-3.408133^{* *}$ & & $-12.28861^{*}$ & $-12.15981^{*}$ \\
LnTF & -2.055476 & $-3.006266^{* *}$ & & $-9.449875^{*}$ & $-10.0691^{*}$ \\
IPI & $-2.601167^{* *}$ & $-2.712786^{* *}$ & & $-4.604915^{*}$ & $-25.91975^{*}$ \\
LnTrade & -1.201907 & -0.919637 & & $-16.06665^{*}$ & $-15.70736^{*}$ \\
LnJCI & -1.692819 & -1.640377 & & $-8.35234^{*}$ & $-8.450634^{*}$ \\
Inf & -0.903283 & -0.866046 & & $-8.734188^{*}$ & $-8.717049^{*}$ \\
\hline Catatan: ${ }^{*},{ }^{* *}$ signifikan pada nilai kritis MacKinnon 1\% dan 5\%. Uji ADP dan PP berdasarkan \\
model intercept
\end{tabular}

Hasil Uji Kointegrasi

Regresi yang menggunakan time series yang tidak stasioner kemungkinan besar akan menghasilkan regresi lancung (spurious regression) (Granger dan Newbold, 1974). Regresi lancung terjadi jika koefisiensi determinasi cukup tinggi tapi hubungan antara variabel independen dan variabel dependen tidak mempunyai makna, atau secara statistik signifikan tetapi tidak memiliki landasan teori yang logis. Hubungan yang terjadi antar variabel hanya hubungan trend saja bukan yang sebenarnya. Untuk mengetahui apakah hasil regresi tidak lancung maka perlu dilakukan uji kointegrasi seperti yang dikembangkan oleh Johansen dan Julious.

Sebagaimana hasil uji unit root pada tabel 2 yang menunjukkan bahwa data series stasioner pada orde pertama atau I (1) maka selanjutnya uji kointegrasi berdasarkan prosedur Johansen bisa dilakukan. Untuk mengetahuan apakah terdapat kointegrasi dalam sistem yaitu dengan menghitung nilai - nilai maximun egenvalue dan trace statitistics. Jika setidaknya terdapat satu vector kointegrasi dalam sistem yang ditandai dengan nilai maximum egenvalue dan trace statistic lebih besar dari nilai statistiknya maka $\mathrm{H}_{0}$ tidak ada kointegrasi ditolak. Keberadaan vector kointegrasi mengindikasikan adanya keseimbangan jangka panjang dalam sistem. 
Tabel 2. Hasil Uji Kointegrasi

\begin{tabular}{|c|c|c|c|c|}
\hline \multicolumn{5}{|c|}{ Model 1} \\
\hline Nul Hyphothesis & Trace Statistic & $\begin{array}{l}0.05 \text { Critical } \\
\text { Value }\end{array}$ & $\begin{array}{l}\text { Max-Eigen } \\
\text { Statistic }\end{array}$ & $\begin{array}{l}0.05 \text { Critical } \\
\text { Value }\end{array}$ \\
\hline$r=0$ & $99.97372^{*}$ & 69.81889 & $55.45089^{*}$ & 33.87687 \\
\hline$r \leq 1$ & 44.52282 & 47.85613 & 25.17451 & 27.58434 \\
\hline$r \leq 2$ & 19.34831 & 29.79707 & 12.15375 & 21.13162 \\
\hline$r \leq 3$ & 7.194562 & 15.49471 & 4.44276 & 14.2646 \\
\hline$r \leq 4$ & 2.751802 & 3.841466 & 2.751802 & 3.841466 \\
\hline \multicolumn{5}{|c|}{ Model 2} \\
\hline Nul Hyphothesis & Trace Statistic & $\begin{array}{l}0.05 \text { Critical } \\
\text { Value }\end{array}$ & $\begin{array}{l}\text { Max-Eigen } \\
\text { Statistic }\end{array}$ & $\begin{array}{l}0.05 \text { Critical } \\
\text { Value }\end{array}$ \\
\hline$r=0$ & $95.99889^{*}$ & 69.81889 & $46.85328^{*}$ & 33.87687 \\
\hline$r \leq 1$ & $49.14561^{*}$ & 47.85613 & 25.27415 & 27.58434 \\
\hline$r \leq 2$ & 23.87146 & 29.79707 & 12.71813 & 21.13162 \\
\hline$r \leq 3$ & 11.15333 & 15.49471 & 7.143159 & 14.2646 \\
\hline$r \leq 4$ & $4.010171^{*}$ & 3.841466 & $4.010171^{*}$ & 3.841466 \\
\hline
\end{tabular}

Catatan: ${ }^{* *}$ menujukkan penolakan pada $\mathrm{H}_{0}$ pada nilai kritikal $5 \%$.

Tabel 2 menyajikan hasil uji kointegrasi Johansen untuk model 1 dan model 2. Uji kointegrasi ini menggunakan lag 4. Pemilihan lag didasarkan atas Akaike Information Criteria (AIC). Menggunakan panjang lag ini, residual pada setiap persamaan VAR bebas dari masalah normalitas dan autokorelasi. Berdasarkan Nilai trace dan maximun eigenvalue statitic pada nilai kritsi $5 \%$, terdapat 1 vector kointegrasi pada model 1 dan 3 vector kointegrasi pada model 2. Hasil ini menandakan bahwa antara variabel pertumbuhan ekonomi (IPI) dan perbankan syariah dan variabel kontrol lain dalam model berhubungan kointegrasi, yakni seluruh variabel cenderung bergerak menuju ekuilibrium dalam jangka panjang. Dengan kalimat lain, dalam setiap periode jangka pendek, variabel pertumbuhan ekonomi (IPI) dan variabel perbankan syariah (LnTD dan LnTF) serta variabel independen lainnya saling menyesuaikan untuk mencapai keseimbangan (ekuilibrium) jangka panjang. Artinya, hasil estimasi regresi tidak spuriuos, tetapi memiliki hubungan jangka panjang antar variabel. Temuan ini sejalan dengan penelitian yang dilakukan oleh Hafas dan Mulyani (2009) sebelumnya. 
Hasil Uji Eror Correction Model dan Granger Causality

Jika hasil uji kointegrasi pada model 1 dan 2 menujukkan adanya keberadaan hubungan kointegrasi jangka panjang dalam sistem maka Vector Error Correction Model (VECM) dilakukan untuk melihat hubungan dinamis jangka pendek pada masing-masing model. Nilai dan signifikasi statistik pada Error Correction Term (ECT) mengukur sejauh mana variabel dependen memiliki kecenderungan untuk kembali ke keseimbangan jangka panjang jika terjadi ketidakseimbangan (disequilibrium) dalam jangka pendek.

Tabel 3. Hasil Estimasi Error Correction Model

\begin{tabular}{|c|c|c|}
\hline Variabels & $\begin{array}{c}\text { Model } 1 \\
\text { Pertumbuhan Ekonomi (IPI) }\end{array}$ & $\begin{array}{c}\text { Model } 2 \\
\text { Pertumbuhan Ekonomi (IPI) }\end{array}$ \\
\hline \multirow{2}{*}{ ECT } & $-0.432824^{*}$ & $-0.606741^{*}$ \\
\hline & & \\
\hline \multirow{2}{*}{ LnTD } & 16.6481 & $04^{*}$ \\
\hline & [ 1.90227$]$ & 0] \\
\hline \multirow{2}{*}{ LnTrade } & 1.2( & \\
\hline & {$[0.1$} & 8] \\
\hline \multirow{2}{*}{ LnJCl } & $13.52116^{* *}$ & 19.12 \\
\hline & {$[2.2$} & \\
\hline & $-1.415027^{*}$ & $-1.247375^{\star *}$ \\
\hline & {$[-3.36619]$} & \\
\hline \multicolumn{3}{|c|}{$\begin{array}{l}\text { Catatan: }{ }^{*},{ }^{* *} \text { menunjukkan signifikan pada nilai kritis } 1 \% \text { dan } 5 \% \text {, nilai dalam kurung adalah } t \\
\text { statistik. }\end{array}$} \\
\hline \multicolumn{3}{|c|}{$\begin{array}{l}\text { Hasil estimasi berdasarkan model error correction (ECM) disajikan pada Tabel } 3 \text {. Hasi } \\
\text { estimasi ECT pada Tabel } 4 \text { adalah negatif dan signifikan secara statistik pada nila } \\
\text { kritis } 1 \% \text { baik pada model } 1 \text { maupun model } 2 \text {. Signifikansi nilai ECT mengkonfirmas } \\
\text { adanya hubungan jangka panjang di antara variabel sebagaimana telah ditunjukkar } \\
\text { oleh uji kointegrasi Johansen sebelumnya. Hasil ini mengindikasikan bahwa variabe } \\
\text { dependen memiliki kecenderungan untuk menyesuaikan terhadap deviasi yang terjad } \\
\text { dalam keseimbangan jangka panjang. Nilai koefisiensi ECT menggambarkar } \\
\text { kecepatan untuk menyesuaikan (speed of adjustment) di antara variabel dalam } \\
\text { keseimbangan jangka panjang dalam suatu periode tertentu. Pada model } 1 \text {, IPI, prox } \\
\text { pertumbuhan ekonomi, mengoreksi sekitar } 43 \% \text { atas deviasi (penyimpangan) yang } \\
\text { terjadi dari hubungan jangka panjang dalam satu periode. Sementara model } 2 \\
\text { terdapat sekitar } 61 \% \text { kemampuan IPI untuk mengoreksi atas deviasi yang terjadi dalam } \\
\text { hubungan jangka panjangnya. }\end{array}$} \\
\hline
\end{tabular}


Selanjutnya, hasil estimasi koefisiensi variabel pada lagged first different diartikan sebagai efek jangka pendek (short-run effect) (Engle dan Granger, 1987). Penelitian ini menemukan bahwa terdapat hubungan positif antara LnTF dengan IPI dan LnTD dan IPI, mengindikasikan bahwa perkembangan perbankan syariah berdampak positif terhadap pertumbuhan ekonomi. Secara statistik LnTF berpengaruh secara signifikan terhadap IPI. Sementara LnTD tidak signifikan secara statistik. Variabel kontrol lain yang secara statistik berpengaruh signifikan terhadap pertumbuhan ekonomi adalah pasar modal dan tingkat inflasi. Hal ini terlihat pada nilai t-statitik variabel LnJCI dan Inf yang signifikan pada level 5\%. Artinya, sektor pasar modal mendorong pertumbuhan ekonomi, dan di sisi lain pertumbuhan ekonomi tidak menyebabkan inflasi - terlihat pada nilai koefisiensi Inf yang negatif terhadap IPI.

Sementara itu, untuk melihat secara spesifik hubungan kausalitas antar variabel, khususnya antara perbankan syariah dengan pertumbuhan ekonomi sebagaimana menjadi fokus pada penelitian ini dapat dilihat melalui uji kausalitas berdasarkan metode Granger atau biasa dikenal Granger Causality test.

Tabel 4. Hasil Uji Granger Causality

\begin{tabular}{lcrr}
\hline \hline Null Hypothesis: & Obs & F-Statistic & \multicolumn{1}{c}{ Prob. } \\
\hline \hline LNTD does not Granger Cause IPI & 109 & 6.59674 & 0.002 \\
IPI does not Granger Cause LNTD & & 8.23199 & 0.0005 \\
\hline LNTF does not Granger Cause IPI & 109 & 7.39954 & 0.001 \\
IPI does not Granger Cause LNTF & & 2.50229 & 0.0868 \\
\hline LNTRADE does not Granger Cause IPI & 109 & 5.69205 & 0.0045 \\
IPI does not Granger Cause LNTRADE & & 4.37837 & 0.0149 \\
\hline Inf does not Granger Cause IPI & 109 & 11.6986 & $3.00 \mathrm{E}-05$ \\
IPI does not Granger Cause Inf & & 2.93696 & 0.0574 \\
\hline LNJCI does not Granger Cause IPI & 109 & 4.67454 & 0.0114 \\
IPI does not Granger Cause LNJCI & & 0.84032 & 0.4345 \\
\hline LNTRADE does not Granger Cause LNTD & 109 & 1.46786 & 0.2352 \\
LNTD does not Granger Cause LNTRADE & & 2.6741 & 0.0737 \\
\hline LNTRADE does not Granger Cause LNTF & 109 & 1.26365 & 0.2869 \\
LNTF does not Granger Cause LNTRADE & & 2.20151 & 0.1158 \\
\hline \hline
\end{tabular}

Hasil uji kausalitas Granger dalam tabel 4, membuktikan bahwa terdapat bi-directional causality antara perbankan syariah dan pertumbuhan ekonomi di Indonesia. Detailnya, LnTD dan IPI berhubungan dua arah yang ditunjukkan pada nilai F-statitiknya yang signifikan pada nilai kritis $1 \%$ atau nilai probabilitasnya di bawah 0.01 . Hubungan dua 
arah juga terlihat pada LnTF dan IPI. Temuan penelitian ini mengkonfirmasi aliran "the bidirectional causality view', yaitu adanya hubungan dua arah atau saling mempengaruhi antara sektor perkembangan keuangan dan pertumbuhan ekonomi. Hipotesis ini menyatakan bahwa sebuah negara yang memiliki perkembangan sektor keuangan yang baik akan mendorong tingkat ekspansi ekonomi yang tinggi melalui kemajuan teknologi dan inovasi produk dan jasa (Schumpeter, 1912).

Kondisi ini kemudian akan menciptakan tingkat permintaan yang tinggi terhadap produk dan layanan perbankan (lihat Levine, 1997). Jika institusi perbankan merespon secara efektif terhadap permintaan tersebut, maka respon tersebut akan menstimulasi kinerja ekonomi yang lebih tinggi. Sektor keuangan dan pertumbuhan ekonomi masingmasing saling berhubungan secara positif dan hubungan ini terjadi secara dua arah (lihat Choong dkk, 2003). Temuan ini sejalan dengan penelitian yang dilakukan oleh Hidayati (2009) dan Hafaz dan Mulyani (2009).

Fenomena bi-directional causality atau hubungan saling mempengaruhi antara pertumbuhan ekonomi (IPI) dan sektor keuangan dalam hal ini perbankan syariah (LnTD dan LnTF) setidaknya dapat dijelaskan sebagai berikut. Di Indonesia, kebijakan pemerintah untuk mempercepat pertumbuhan ekonomi melalui peningkatan investasi menyebabkan perkembangan sektor keuangan khususnya lembaga perbankan termasuk perbankan syariah di dalamnya, melalui kenaikan pembiayaan/kredit sebagai alternatif pembiayaan untuk ekspansi usaha. Hal ini, selanjutnya membawa perkembangan pada sektor perbankan dan jasa-jasa keuangan lainnya, guna memfasilitasi investasi dan akhirnya menghasilkan pertumbuhan ekonomi. Sebaliknya, pertumbuhan ekonomi melalui peningkatan aktivitas ekonomi dan investasi membutuhkan lebih banyak modal atau likuiditas yang di-supply atau disediakan oleh institusi-institusi keuangan dan selanjutnya mendorong munculnya produk-produk inovasi keuangan yang beraneka ragam. Inilah makna hubungan bi-directional causality antara sektor keuangan dan pertumbuhan ekonomi.

Aktivitas perdagangan (LnTrade), ekspor-impor juga berhubungan dua arah dengan pertumbuhan ekonomi (IPI). Sektor luar negeri melalui kegiatan ekspor-impor diyakini oleh para pemikir ekonomi dari dulu sampai sekarang berpengaruh secara positif terhadap pertumbuhan ekonomi. Ekspor barang dan jasa ke luar negeri akan menciptakan arus modal masuk ke dalam negeri dan akan menjadi pendapatan nasional melalui neraca perdagangan. Begitu pula dengan kegiatan impor khususnya 
barang-barang modal untuk kebutuhan ekspansi produksi akan berdampak pada pertumbuhan ekonomi domestik. Semakin tinggi tingkat pertumbuhan ekonomi, otomatis akan meningkatkan kemampuan produksi barang dan jasa yang sebagiannya untuk memenuhi pasar luar negeri dan di sisi lain akan meningkatkan permintaan bahan-bahan modal berunsur impor untuk memenuhi permintaan akibat pertumbuhan ekonomi yang tinggi.

Temuan menarik selanjutnya adalah bahwa terjadi hubungan saling mempengaruhi antara pertumbuhan ekonomi dan tingkat kenaikan harga, ditunjukkan pada nilai Fstatistik hasil uji Granger Causality pada IPI dan Inf yang signifikan. Artinya, pertumbuhan ekonomi di Indonesia justru menyebabkan terjadinya inflasi. Kondisi ini kemungkinan disebabkan oleh peningkatan konsumsi sebagai akibat pertumbuhan ekonomi yang progresif menyebabkan terjadinya kelebihan permintaan atas barang dan jasa. Akan tetapi di sisi lain tidak diikuti oleh peningkatan investasi untuk memenuhi lonjakan permintaan tersebut. Akibatnya terjadi kenaikan harga (inflasi) sebagai akibat permintaan yang lebih banyak dibandingkan dengan penawaran yang tersedia. Kondisi ini biasa disebut sebagai overheating.

Hubungan satu arah secara signifikan justru terjadi pada sektor keuangan (perbankan syariah) terhadap aktivitas perdagangan, LnTD berhubungan kausalitas terhadap LnTrade. Temuan ini mengindikasikan bahwa perbankan syariah melalui mobilisasi dana dari masyarakat dalam berbagai bentuk tabungan dan deposito menjadi sumber alternatif pembiayaan bagi sektor yang bergerak dalam bidang perdagangan (eksporimpor). Sebaliknya, LnTF tidak berkausalitas terhadap kegiatan perdagangan (LnTrade). Di sisi lain, pasar modal yang direpresentasikan oleh Jakarta Composite Index (LnJCl) berkausalitas secara signifikan terhadap pertumbuhan ekonomi. Artinya semakin tinggi aktivitas ekonomi yang terjadi di pasar modal, akan berdampak pada pertumbuhan ekonomi.

\section{SIMPULAN}

Dengan menggunakan uji statistik, penelitian ini mengeksplorasi secara empiris hubungan jangka pendek dan jangka panjang antara pertumbuhan ekonomi dengan sektor keuangan khususnya perbankan syariah dan variabel kontrol lainnya untuk studi kasus Indonesia. Penelitian ini juga berusaha menganalisis hubungan kausalitas antara pertumbuhan ekonomi dengan perbankan syariah di tanah air. 
Berdasarkan hubungan kausalitas Granger di antara variabel, penelitian ini menemukan hubungan bi-directional causality antara perkembangan perbankan syariah dengan pertumbuhan ekonomi. Temuan ini sejalan dengan hipotesis "the feedback hypthesis" atau "the bidirectional causality view". Hasil empiris ini membuktikan bahwa pertumbuhan perbankan syariah di Indonesia dapat mendorong ekspansi ekonomi yang tinggi melalui bentuk-bentuk produk dan layanan yang sesuai syariah. Tentunya, hal ini sejalan dengan karakter dari perbankan syariah itu sendiri yang sangat pro dan menekankan sektor ekonomi riil. Jika lembaga keuangan perbankan syariah secara efektif merespon atas kenaikan permintaan sebagai akibat pertumbuhan ekonomi tinggi, perubahan ini kemudian akan menstimulasi prestasi ekonomi yang lebih tinggi. Perkembangan sektor perbankan dan ekonomi pada akhirnya akan saling membutuhkan dan hubungan mereka akan mendorong terjadinya bi-diorectional causality.

Melalui hasil penelitian ini juga, perbankan syariah telah secara efektif memainkan perannya sebagai lembaga intermediasi yang memfasilitasi mobilisasi modal dari unit surplus ke unit defisit, sektor ekonomi yang memiliki kelebihan modal ke sektor ekonomi yang membutuhkan pembiayaan. Oleh karena itu, kita dapat mengatakan bahwa kebijakan Bank Sentral Indonesia dan lembaga otoritas lainnya yang terkait untuk mengembangkan sistem keuangan Islam yang komprehensif di Indonesia di nilai efektif selama perkembangan sektor keuangan dan pertumbuhan ekonomi/sektor riil saling berhubungan secara kuat. Penelitian ini juga mengindikasikan bahwa peningkatan infrastruktur perbankan syariah di Indonesia akan memberikan manfaat terhadap perkembangan ekonomi dan hal ini penting dalam jangka panjang untuk perkembangan kesejahteraan masyarakat.

Pengembangan perbankan syariah dan industri keuangan adalah salah satu pilihan kebijakan yang sangat relevan untuk mendorong pertumbuhan ekonomi dan sektor riil di Indonesia. Menyediakan kebijakan dan kondisi lingkungan yang kondusif buat perkembangan perbankan syariah secara terus-menerus dalam jangka panjang, akan mendorong perbankan syariah untuk berkontribusi pada pertumbuhan ekonomi nasional. Setelah melihat hasil penelitian ini maka diharapkan ada usaha-usaha yang berkesinambungan dari pihak pemerintah dan para pelaku perbankan syariah untuk mendorong perkembangan perbankan syariah di tanah air sebagai salah satu bagian dari sistem perbankan nasional yang akan berkontribusi pada pengembangan sektor 
ekonomi riil di Indonesia. Perbankan syariah diharapkan untuk tetap konsisten pada pola pembiayaan sektor riil dan Usaha Mikro Kecil dan Menengah (UMKM) yang selama ini digelutinya. Pola pembiayaan ini secara ekonomi telah berkontribusi pada pengurangan pengangguran dan kemiskinan seta mendorong pertumbuhan sektor ekonomi riil.

Meningkatkan infrastruktur keuangan seperti peningkatan kuantitas dan kualitas sumber daya manusia untuk memenuhi permintaan industri keuangan syariah yang diprediksi akan mengalami pertumbuhan yang cukup pesat di masa-masa mendatang. Menyediakan perangkat hukum yang memadai sebagai bentuk regulatory framework bagi pelaku-pelaku industri keuangan syariah. Sistem manajemen risiko juga menjadi hal penting untuk mendukung perkembangan indsutri ini dalam jangka panjang. Terakhir, memastikan stabilitas pasar keuangan syariah untuk menjaga stabilitas makro ekonomi Indonesia.

\section{PUSTAKA ACUAN}

Acaravei, Ali., Ilham, O. dan Kakilli, S. 2007. Finance - Growth Nexus: Evidance frm Turkey. International Research Journal of Finance and Economics, Issue 11.

Al-Zubi, K., et. al. 2006. Financial Development and Economic Growth: A New Empirical Evidance from the Mena Countries 1989-2001. Journla of Applied Econometrics and International Development, Vol, 6, No.1, hlm. 3-11.

Arestis, P. dan P. Demetriades. 1996. Finance and Growth: Institutional Consideration and Causality. UEL Depertement of Economics Working Paper.

Black burn, K. dan Hung, V.T.Y. 1998. A Theory of Growth, Financial Development and Trade. Economica. Vol.3, No. 65, hlm. 107-124.

Choong, C. K., et. al. 2003. Financial development and economic growth in Malaysia: the stock market perspective. Economic Working Paper Archive at WUSTL Macroeconomics.

Darrat, A. F. 1988. The Islamic Interest-Free Banking System: Some Empirical Evidance. Applied Economics. 20, hlm. 417-425.

Demetriades, P.O. and Husein, K.A. 1996. Dos Financial Development Cause Economic Growth? Time Series Evidance from 16 Countries. Journal of Development Economics. 51, hlm. 387-411.

Domar, E. 1946. Capital expansion, rate of growth, and employment. Econometrica. 14 No. 2, hlm. 137-147.

Fase, M. M. G. and Abma, R. C. N. 2003. Financial Environment and Economic Growth in selected Asian Countries. Journal of Asain Economics. Vol. 14, hlm. 11-21. 
Granger, C.W.J. and Newbold, P. 1974. Spurious Regression in Econometrics. Journal of Econometrics, Vol. 2, hlm. 111-120.

Gujarati, D and Porter. 2009. Basic Econometrics. New York: McGraw-Hill.

Guryay, E., et. al. 2007. Financial Development and Economic Growth: Evidance from Northern Cyprus. International Rsearch Journal of Finance and Economics. Issue 8, hlm. 57-62.

Habibullah, M.S. dan Eng, Y. 2006. Does Financial Development Cause Economic Growth? A Panel Data Dynamic Analysis for the Asian Developing Countries. Journal of Asia Pacific Economy, 11, hlm. 377-393.

Habibullah, M.Z., and Eng, Y.K. 2006. Does financial development cause economic growth? a panel data dynamic analysis for Asian developing countries. Journal of the Asian Pacific Economy. Vol. 11, No. 4, hlm. 377-393.

Hafas, Furqani and Mulyany, Ratna. 2009. Islamic Banking and Economic Growth: Empirical Evidance from Malaysia. Journa of Economic Cooperation and Development. 30, 2, hlm. 59-74.

Harrison, P., et. al. 1999. Finance and Growth: Theory and New Evidance. Federal Reserve Board Finance and Economics Discussion Paper. 1999-35.

Harrod, R. 1939. An essay in dynamic theory. The Economic Journal. 49, hlm. 14-33.

Hidayati, Siti. 2009. Analisis Hubungan Kinerja Sistem Keuangan (Perbankan dan Pasar Modal terhadap Pertumbuhan Ekonomi Indonesia Periode 1990-2008 (Tesis Tida Dipublikasikan). Depok : Universitas Indonesia.

King, R.G. and Levine, R. 1993. Finance, Entrepreneurship, and Growth. Journal of Monetary Economics. 32, hlm. 513-542.

Levine, R. 1997. Financial development and economic growth: views and agenda. Journal of Economic Literature. 35(2), hlm. 688-726.

Lewis, W.A. 1954. Economic development with unlimited supplies of labour. The Manchester School. 22, hlm. 139-191.

Lucas, R.E. 1988. On the mechanics of economic development. Journal of Monetary Economics. 22(1), hlm. 3-42.

Luintel, K. B., and M. Khan. 1999. A Quantitative Reassessment of the Finance-Growth Nexus: Evidance from A Multivariate VAR. Journal of Development Economics. 60, hlm. 381-405.

Odedokun, M. O. 1992. Supply-Leading and Demand-Following Relationship between Activity and Development Banking in Developing Countries: An Empirical Analysis. Singapore Economic Review. 37, hlm. 46-58.

Rama, Ali. 2011. Determinants Affecting Deposit and Financing of Islamic Banks: Evidence from Indonesia, Thesis Program Master of Economics International Islamic University Malaysia (IIUM). 
Robinson, J. 1952. The generalization of the general theory. In The rate of interest and Other Essays. London: MacMillan.

Rostow, W.W. 1960. The Stages of Economic Growth: A Noncommunist Manifesto. London: Cambridge University Press.

Schumpeter, J.A. 1912. A Theory of Economic Development. Cambridge, MA: Harvard University Press.

Solow, R. 1956. A contribution to the theory of economic growth. Quarterly Journal of Economics. 70, hlm. 65-94.

Chapra, Umar. 2008. Reformasi Ekonomi: Sebuah Solusi Perspektif Islam, terjemahan oleh Ikhwan Abidin Basri. Jakarta: Bumi Aksara.

Unalmis, D. 2002. The Causality between Financial Development and Economic Growth: The Case of Turkey. The Central Bank of the Turkish Republic, Research Department Working Paper, No: 3, June.

Widarjono, Agus. 2009. Ekonometrika: Pengantar dan Aplikasinya. Yogyakarta: Ekonosia Fakultas Ekonomi UII.

Xu, Z. 2000. Financial Development, Investment, and Economic Development. Economic Inquiry. 38, hlm. 331-344.

Yousefi, Mahmud., et al. 1997. Monetary Stability and Islamic Banking: The case of Iran. Applied Economics. 29, hlm. 869-876.

Yusof, Remali dan Wilson, Rodney. 2005. An Economic Analysis of Conventional and Islamic Bank Deposits in Malaysia. Review of Islamic Economics. 9, 1, hlm. 3152. 